\title{
Enhanced Properties of Single-Layer Particleboard Made from Oil Palm Empty Fruit Bunch Fibre with Additional Water-Soluble Additives
}

\author{
Chuan Li Lee, ${ }^{a}$ Kit Ling Chin, ${ }^{\mathrm{a}, *}$ Paik San H'ng, ${ }^{\mathrm{a}, \mathrm{b}, *}$ Pui San Khoo, ${ }^{\mathrm{a}}$ and \\ Luqman Abdullah Chuah $^{\text {a }}$
}

\begin{abstract}
The efficacy of additional water-soluble additives was studied relative to the physical and mechanical properties of particleboards produced from oil palm empty fruit bunch (OPEFB). Polyethylene glycol, acrylamide, and acrylic resin were selected as water-soluble additives for use in the OPEFB particleboard production process. The effects of the three additives at two different concentrations ( $2 \%$ and $4 \%$ of dry OPEFB mass) on the particleboard properties were evaluated. Addition of water-soluble additives increased the performance of the OPEFB particleboard. The additive concentration has a significant effect on the properties of the particleboard. With the increase of additive concentration, the internal bonding and modulus of rupture value increased while the thickness swelling and water absorption decreased. Particleboards with an additional $4 \%$ of acrylamide or polyethylene glycol achieved the highest modulus of rupture $(22 \mathrm{MPa})$, highest internal bonding strength $\left(1 \mathrm{~N} / \mathrm{mm}^{2}\right)$, and lowest thickness swelling (9\%). All the particleboards produced with $4 \%$ of water-soluble additive achieved the standard requirements of JIS A 5908:2003 for physical and mechanical properties.
\end{abstract}

Keywords: Particleboard; Empty fruit bunch; Water-soluble additive; Acrylic resin; Acrylamide; Polyethylene glycol

Contact information: a: Institute of Tropical Forestry and Forest Products, Universiti Putra Malaysia, 43400 UPM Serdang, Selangor, Malaysia; b: Faculty of Forestry and Environmental, Universiti Putra Malaysia, 43400 UPM Serdang, Selangor, Malaysia;

*Corresponding authors: ngpaiksan@gmail.com; kitling.chin419@gmail.com

\section{INTRODUCTION}

Wood is one of the most abundant biomaterials and has piqued the interest of researchers in both academia and industry. Due to its high strength-to-weight ratio, renewable nature, and environmentally friendly nature, high quality solid wood has been used extensively in construction and furniture for thousands of years. As a significant part of the global manufacturing sector, China's furniture market reached almost USD 600 billion in 2018 (Xiong et al. 2020). In addition, wood has gradually attracted greater attention from the latest global trends for the improvement of living standards and increasing concerns about environmental protection (Popescu and Pfriem 2020). Regrettably, high-quality solid wood is currently experiencing reduced supply due to low growth rates and stricter global environmental regulations (Qiu et al. 2018). These issues have led the scientific research to look for new alternatives to replace traditional polymer composites, looking for ways that have lower environmental impact and thus are often referred to as "ecocomposites" or "biocomposites" (La Mantia and Morreale 2011). Hence, biocomposites are an important development trend in the modern manufacturing industry 
as a new manufacturing approach.

In the furniture industry, particleboard is one of the most commonly used composite panels due to its versatility and low cost (Owodunni et al. 2020). Malaysia is one of the world's important players for export of particleboard. According to the Malaysian Timber Industry Board (MTIB), the total exports for particleboard were $68,489 \mathrm{~m}^{3}$ and valued at RM85.3 million in 2017 (Harun 2018). Wood-based industry players are continually in a race to explore new potential resources for continuous stable production to meet the future demand. In Malaysia, the main raw material used in the production of particleboard is rubberwood. Syeed et al. (2019) reported that at least 4 out of 7 particleboard mills in Malaysia used solely rubberwood for particleboard production with a total installed capacity of approximately $1530 \mathrm{~m}^{3} /$ day. Rubberwood is a mass-produced wood that is now being used and marketed for higher-value applications, including the wood panels, pulp and paper, as well as latex production. The Covid-19 pandemic has cast the spotlight on Malaysia's rubber industry, particularly on downstream latex players such as glove makers. At present, the manufacturing of gloves is mainly focused on natural latex gloves, which account $40 \%$ for the total production of glove in Malaysia (Surendran and Ng 2020). Due to the high consumption rate of rubberwood in various other industries, the particleboard industry continues to seek other diverse sources of raw materials and to meet the high demand for particleboard.

One of the ideal raw materials for particleboard production in Malaysia is oil palm empty fruit bunch (OPEFB). Malaysia is one of the world's largest palm oil producers and exporters (Chin et al. 2019). The total export of products based on palm oil in the country amounted to 25.2 million tonnes, generating export earnings of RM67.5 billion (Yusof 2019). The palm oil mill generated a large volume of solid waste residues, including 5.5$8 \%$ palm kernel shell, $20-23 \%$ OPEFB and $15 \%$ palm fibre from fresh fruit bundles (Rahayu et al. 2019). In comparison with rubberwood, OPEFB is an under-utilized resource. It has various potential applications as long as suitable pretreatments or processing methods have been determined and carried out (Killmann and Hong 2000). Substantially, various research and development activities aim to explore the used of the enormous waste from the palm oil industry as an alternative source and innovative reliable raw material for high demand products (Peter et al. 2020).

The abundant availability of OPEFB has gained continuous interest among researchers and is potentially considered as the main candidate to substitute woody materials due to the shortage of resources. However, until today OPEFB is hardly accepted by particleboard manufacturers due to the hygroscopic characteristics of the OPEFB fibre itself (Ismail et al. 2012). Without any treatment, particleboard made from OPEFB is unable to achieve the JIS A 5908 standard on the physical and mechanical properties of particleboard, including tensile strength, internal bonding, water absorption, thickness swelling, and density (Zaidon et al. 2007). It is impossible to develop a market for OPEFB particleboard without overcoming these restrictive parameters.

Biocomposites can be used in a variety of industrial applications. However, there are some issues, such as reduction of the ductility and poor processability. Many of these limitations can be overcome with the use of adhesion promoters, additives, or chemical modifications to the filler. According to Brahmia et al. (2020) and Wei and Tomita (2001), the mechanical properties and dimensional stability of cement-wood composite were significantly improved with increasing amounts of the additives. Unlike for the cementwood composites, the concept of the usage of additives has not yet been investigated for 
particleboard. To date, the most fundamental question on how addition of additive effects on the physical and mechanical strength on the particleboard remain unanswered.

Among these, water-soluble and biodegradable polymer matrixes would be a better choice to be utilized for biocomposite production. According to Fredi et al. (2019), watersoluble additives can penetrate deeply into the heartwood, thus offering prospects of greater protection of the wood. Acrylamide is a water-soluble monomer that is biodegradable and widely used in a variety of chemical and environmental included production of plastics, dyes, and paper, in the treatment of drinking water, wastewater, and sewage (Kusnin et al. 2015; Tepe and Çebi 2019). Water-soluble polyethylene glycol (PEG) is a well-known compound with a wide range of medical and industrial applications (Chen et al. 2005, 2007; Vafaeezadeh and Hashemi 2015). It is inexpensive and significantly less hazardous than other potential additives that require organic solvents. In addition, PEG products are stable under ambient conditions because they have negligible vapour pressure and do not release volatile organic compounds (Vafaeezadeh and Hashemi 2015). As stated by Behzad and Sain 2004, a new environmentally friendly curable acrylic resin was characterized to develop a high-performance biocomposite for future work. A significant problem concerning the scientific application of curable acrylic resins is their biodegradation (Vivek 2017). Moreover, water-soluble acrylic resin is a potential zero formaldehyde emission binder for particleboard production (Amazio et al. 2011).

This paper presents the methods and the efficiency results from an experimental investigation of water-soluble additives mixed with urea formaldehyde resin for the production of single-ply OPEFB particleboard. Additional water-soluble additives were tested, with the aim to reduce water absorption and to improve dimensional stability and mechanical properties of the OPEFB particleboard. The purpose of the investigation was to determine the effect of different types of water-soluble additives (PEG, acrylic resin and acrylamide) and concentrations (2\% and 4\% of dry OPEFB mass) of water-soluble additives on the physical and mechanical properties of the OPEFB particleboard. The results obtained were used to analyse the changes in the physical and mechanical properties of single-ply OPEFB particleboard with water-soluble additives and urea formaldehyde resin mixture. The differences may become visible by comparing the physical and mechanical test result and can be explained by the varying influence of the concentration of additives on the OPEFB particleboard.

\section{EXPERIMENTAL}

\section{Material}

OPEFB fibres were collected from the Hulu Langat Oil Palm Mill, Selangor. Urea formaldehyde (UF) Type E1 resin was provided by Dynea Malaysia Sdn Bhd. Three types of additives (PEG, curable Acrylic Resin, Acrylamide) used in this study were provided by CYTEC Chemical.

\section{Methods}

Single-layer particleboard production

In order to obtain particles with the size of 1.5 to $3.0 \mathrm{~mm}$, OPEFB was flaked and sieved. The OPEFB particles were further dried prior to the production of particleboard to achieve a final moisture content below $6 \%$. The targeted density of the particleboard was 
$700 \mathrm{~kg} / \mathrm{m}^{3}$ and the size was $350 \mathrm{~mm}$ x $350 \mathrm{~mm}$ x $12 \mathrm{~mm}$. Seven types of particleboards were produced with 5 replicates each (Table 1). A mixture of $11 \% \mathrm{E} 1 \mathrm{resin}, 0.5 \%$ wax, and additives was sprayed on the OPEFB particles and mixed for 5 minutes. In the resin mixture, three types of water-soluble additives (PEG, acrylic resin, acrylamide) with two different concentrations ( $2 \%$ and $4 \%$ of dry OPEFB mass) were used, respectively. Particleboard without additional water-soluble additives were used as control samples.

The blended OPEFB particles were uniformly dispersed in a $350 \mathrm{~mm}$ x $350 \mathrm{~mm}$ wood box and cold-pressed for 5 minutes. The mat formation was hot-pressed at $100 \mathrm{MPa}$, $180{ }^{\circ} \mathrm{C}$ for $5 \mathrm{~min}$. The particleboards were placed in the conditioning room with the relative humidity of conditioning room $65 \pm 5 \%$ and temperature of $23 \pm 3{ }^{\circ} \mathrm{C}$ until constant weight was reached. The particleboard's physical and mechanical properties were tested in compliance with the Japanese Industrial Standard (JIS) A5908:2003. Each of the conditioned particleboards was later trimmed and cut into testing specimens according to the JIS standard.

Table 1. Seven Types of Particleboards

\begin{tabular}{|c|c|c|}
\hline Treatment ID & Type of additives & Additives concentration (\%) \\
\hline PG2 & Polyethylene glycol & 2 \\
\hline PG4 & Polyethylene glycol & 2 \\
\hline AM2 & Acrylamide & 4 \\
\hline AM4 & Acrylamide & 2 \\
\hline AC2 & Acrylic resin & 4 \\
\hline AC4 & Acrylic resin & \multicolumn{2}{|c|}{ Without additional additives } \\
\hline WAA & \multicolumn{2}{|c|}{}
\end{tabular}

Note: UF resin was present in every condition, including the WAA.

\section{Moisture content and density}

According to JIS A 5908:2003, the air-dry density of test specimens with dimension of $50 \mathrm{~mm}$ by $50 \mathrm{~mm}$ was determined by weighing the specimens and measuring the volume of specimens. The density was calculated using the following formula:

$$
\text { Density }\left(\frac{\mathrm{kg}}{\mathrm{m}^{3}}\right)=\frac{\text { Mass }}{\text { Volume }}
$$

Specific gravity of test specimens was determined by dividing the oven-dry density of the specimens with density of water. Moisture content of the specimens was determined using conventional drying method according to JIS A 5908:2003. The specimens were oven-dried at temperature of $103 \pm 2{ }^{\circ} \mathrm{C}$ to constant weight in order to determine the ovendry weight. The moisture content of the specimens was calculated as follows:

$$
\text { Moisture Content }(\%)=\frac{\text { Initial Weight }(\mathrm{g})-\text { Oven-dry Weight }(\mathrm{g})}{\text { Oven-dry Weight }(\mathrm{g})} \times 100 \%
$$

\section{Water absorption and thickness swelling}

Test specimens with dimensions of $50 \mathrm{~mm}$ by $50 \mathrm{~mm}$ were weighed, and the dimensions were measured prior to submergence in $25 \mathrm{~mm}$ of distilled water at a temperature of $20 \pm 1{ }^{\circ} \mathrm{C}$. After $2 \mathrm{~h}$ of submersion, the water was removed and the specimens were drained for $10 \pm 2 \mathrm{~min}$ in order to remove excess surface water. The specimens were weighed, and the thickness of the specimens was measured immediately. The specimens were then submerged for a further $22 \mathrm{~h}$. After submersion, the percentage 
of water absorption and thickness swelling (based on the JIS A 5908:2003) were determined using the formula as follows:

$$
\begin{aligned}
& \text { Water Absorption }(\%)=\frac{\text { Final Weight }(\mathrm{g})-\text { Initial Weight }(\mathrm{g})}{\text { Initial Weight }(\mathrm{g})} \times 100 \% \\
& \text { Thickness Swelling }(\%)=\frac{\text { Final Thickness }(\mathrm{mm})-\text { Initial Thickness }(\mathrm{mm})}{\text { Initial Thickness }(\mathrm{mm})} \times 100 \%
\end{aligned}
$$

\section{Static Bending}

Flatwise and edgewise three-point static bending tests were carried out on specimens with dimension $50 \mathrm{~mm}$ width by $180 \mathrm{~mm}$ length using INSTRON Universal Testing Machine in accordance to JIS A 5908:2003. The crosshead loading speed was kept at $10 \mathrm{~mm} / \mathrm{min}$ continuously throughout the test. With the formula, the bending strength was calculated as in Eq. 5,

$$
\operatorname{MOR}\left(\mathrm{N} / \mathrm{mm}^{2}\right)=\frac{3 F L}{2 \mathrm{bh}^{2}}
$$

where $F$ is the load at the fracture point $(\mathrm{N}), L$ is the length of the support span $(\mathrm{mm}), b$ is the width of specimen (mm), and $h$ is the thickness of specimen (mm).

\section{Internal bonding (IB)}

Test specimens were cut to $50 \mathrm{~mm}$ x $50 \mathrm{~mm}$ were used for testing. Hot-melt resin was used to adhere both surfaces of each specimen on to two steel blocks. A tension load was applied vertically to the board surfaces, and the maximum load was measured at the time of failing force (breaking load of perpendicular tensile strength to the board). IB was calculated using Eq. 6,

$$
\text { IB }\left(\mathrm{N} / \mathrm{mm}^{2}\right)=\frac{P}{2 \mathrm{bL}}
$$

where $\mathrm{P}$ is the maximum load at the time of failing force $(\mathrm{N}), b$ is the width of the sample (mm), and $L$ is the length of the sample (mm)

\section{Data analysis}

Statistical analyses were carried out using the statistical package SPSS for Windows, version 16.0 (SPSS, Chicago, IL, USA) to evaluate the data of physical and mechanical properties of particleboard for analysis of variance (ANOVA) at $95 \%$ confident level $(\mathrm{P} \leq 0.05)$. Regression analysis was conducted to evaluate the significance of the relationship between relevant variables. In order to further determine the levels of significance of average values for each treatment, Duncan's multiple range test was applied to analyse the differences of the treatment effects when significant difference was observed. The effects were considered not statistically significant when the p-value was higher than 0.05 at the $95 \%$ confidence level.

\section{RESULTS AND DISCUSSION}

The physical and mechanical properties of the OPEFB particleboard manufactured with different treatment parameters (types and concentrations of the water-soluble additive) were evaluated in this study. The analysis of the effect of the types and the concentration of additional water-soluble additives on the properties of the OPEFB particleboard is presented in Table 2. For all the models, the p-value was less than 0.01 for all parameters; 
type of additives, concentration, and the interaction of the two factors, indicating that all parameters significantly affect the properties of the particleboards.

Table 2. ANOVA for the Effect of Additive to the Performance of OPEFB Particleboard

Notes:

\begin{tabular}{|c|c|c|c|}
\hline Source & Dependent Variable & $\mathrm{F}$ & Sig. \\
\hline \multirow{3}{*}{$\begin{array}{c}\text { Type of Additive } \\
\mathrm{x} \\
\text { Concentration of } \\
\text { Additive }\end{array}$} & Board Density & 10.104 & $.000^{* *}$ \\
\cline { 2 - 4 } & Thickness Swelling (TS) & 30.216 & $.000^{\star *}$ \\
\cline { 2 - 4 } & Water Absorption (WA) & 17.024 & $.000^{\star *}$ \\
\cline { 2 - 4 } & Internal Bonding (IB) & 4.752 & $.002^{\star *}$ \\
\cline { 2 - 4 } & Modulus of Rupture (MOR) & 4.120 & $.014^{*}$ \\
\hline
\end{tabular}

* Significant, $p<0.05 ;{ }^{* *}$ Highly Significant, $p<0.01 ;{ }^{n s}$ Not significant, $p>0.05$

\section{Effect of the Additional Additive to the Physical Properties of Particleboard}

The analysis of physical properties (density, thickness swelling, and water absorption) for OPEFB particleboard is shown in Figs. 1, 2, and 3, respectively.

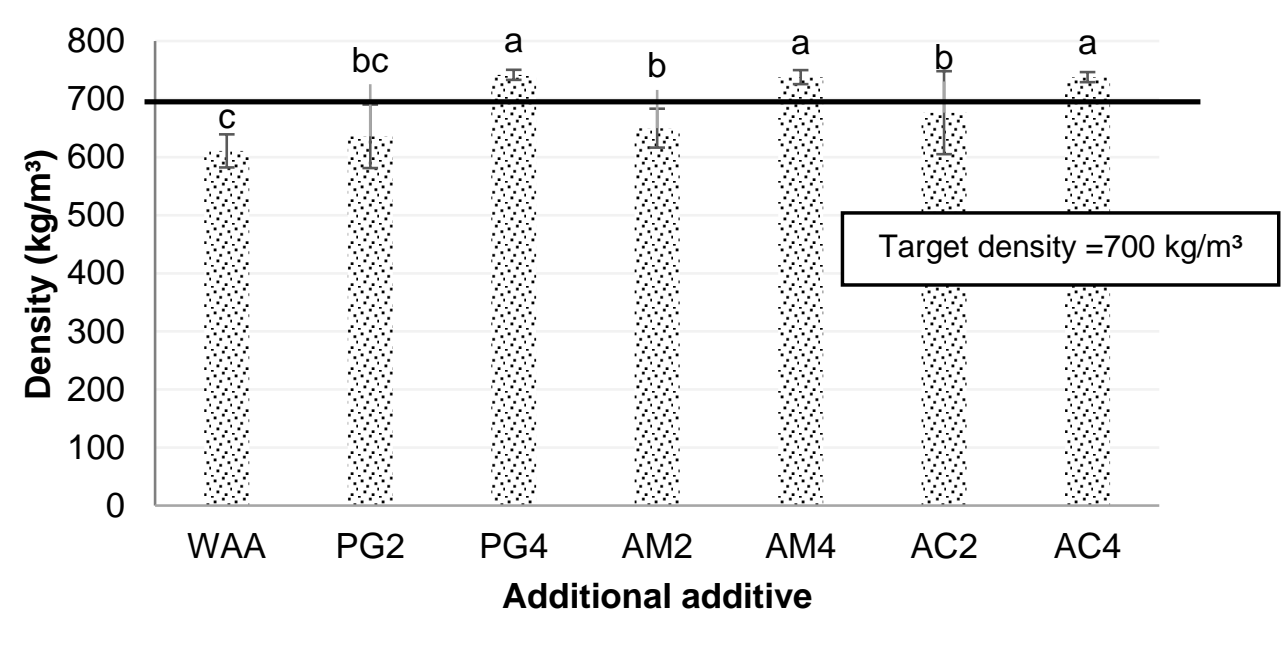

Fig. 1. Mean value of density of the particleboard

Notes: Means followed by the same letters are not significantly different at $p \leq 0.05$ according to Duncan's multiple range test. The $p$-values reveal the strength of differences between factors (types of concentration $x$ concentration of additive) on the density of the OPEFB particleboard.

UF resin was present in every condition, including the WAA.

In this study, the target density for the OPEFB particleboard was $700 \mathrm{~kg} / \mathrm{m}^{3}$. Figure 1 shows that particleboards with a higher additive concentration were significantly higher in density compared to particleboards with a lower additive concentration. This outcome reveals that the particleboard with a higher additive concentration improved the bonding without increasing resin content. Regardless of the types of additives, particleboard with $4 \%$ concentration of additive achieved the target density of $700 \mathrm{~kg} / \mathrm{m}^{3}$. The target density of $700 \mathrm{~kg} / \mathrm{m}^{3}$ was not achieved by particleboards with $2 \%$ additive concentration and without any use of additive. In other words, the density of the particleboard substantially 
depends on the additive concentration. According to Sumardi and Suzuki (2014), thickness swelling and water absorption of the particleboard are affected by the board density.

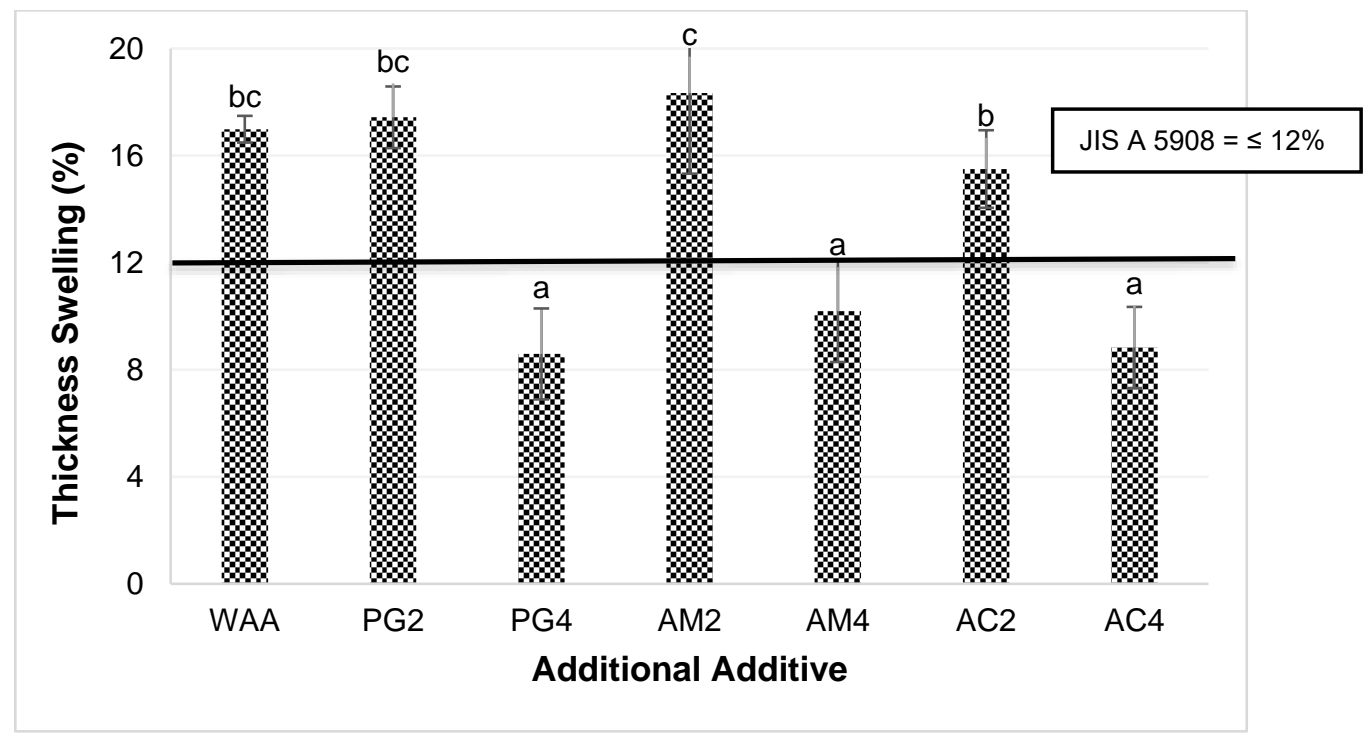

Fig. 2. Mean value of thickness swelling of the particleboard

Notes: Means followed by the same letters are not significantly different at $p \leq 0.05$ according to Duncan's multiple range test. The $p$-values reveal the strength of differences between factors (types of concentration $x$ concentration of additive) on the thickness swelling of the OPEFB particleboard. UF resin was present in every condition, including the WAA.

Heebink and Hefty (1968) claimed that it is very difficult to produce particleboards with minimal thickness swelling. According to the requirements of JIS A 5908:2003, the thickness swelling of particleboard shall not exceed 12\%. Additives were employed with the aim to reduce the thickness swelling and to open new possibilities for particleboard produced from OPEFB. The results showed that a higher additives concentration of $4 \%$, regardless of the types used in this study, produced particleboards with lower thickness swelling and reached the requirement of JIS A 5908:2003 (Fig. 2). With 2\% concentration of additives, the thickness swelling was similar to non-treated particleboard, which indicated the insufficiency on the amount of additive to effectively reduce the thickness swelling. PG4 has the lowest thickness swelling (8.59\%), followed by AC4 (8.83\%) and AM4 (10.19\%).

The fact that particleboard with PEG additive achieved the lowest thickness swelling which may due to the bulking effect of PEG filling up the cavities and eventually reducing the extent of swelling (Radzi et al. 2019). This result was also reported by Meints et al. (2018) that PEG is able to reduce the water-holding capacity simultaneously by crosslinking the cellulose chains of the component fibres. In addition, the additives acted as plasticizers and allowed the UF resin to be more effective in forming a strong connection between the solid surfaces have contributed to the improvement of water and moisture resistance. As stated by Mekonnen et al. (2013), PEG by acting as a plasticizer can reduce the chain-to-chain interaction and induce flexibility, moisture resistance and ease of processability. Thermoplastic toughening, by incorporating thermoplastics to prepare highperformance structural composites, has been widely used in materials science (Huang et al. 1993; Gopala et al. 1998; Luo et al. 2019). Das et al. (2008) revealed that by mixing 
curable acrylic resin (thermoplastic additive) with UF resin (thermosetting amino resin) had improved impact strength via in situ polymerization. This has also contributed to the prevalent use of curable acrylic resin as a coating to protect wood surfaces from stains, scratches, water rings, and other types of damage (Ammar et al. 2019).

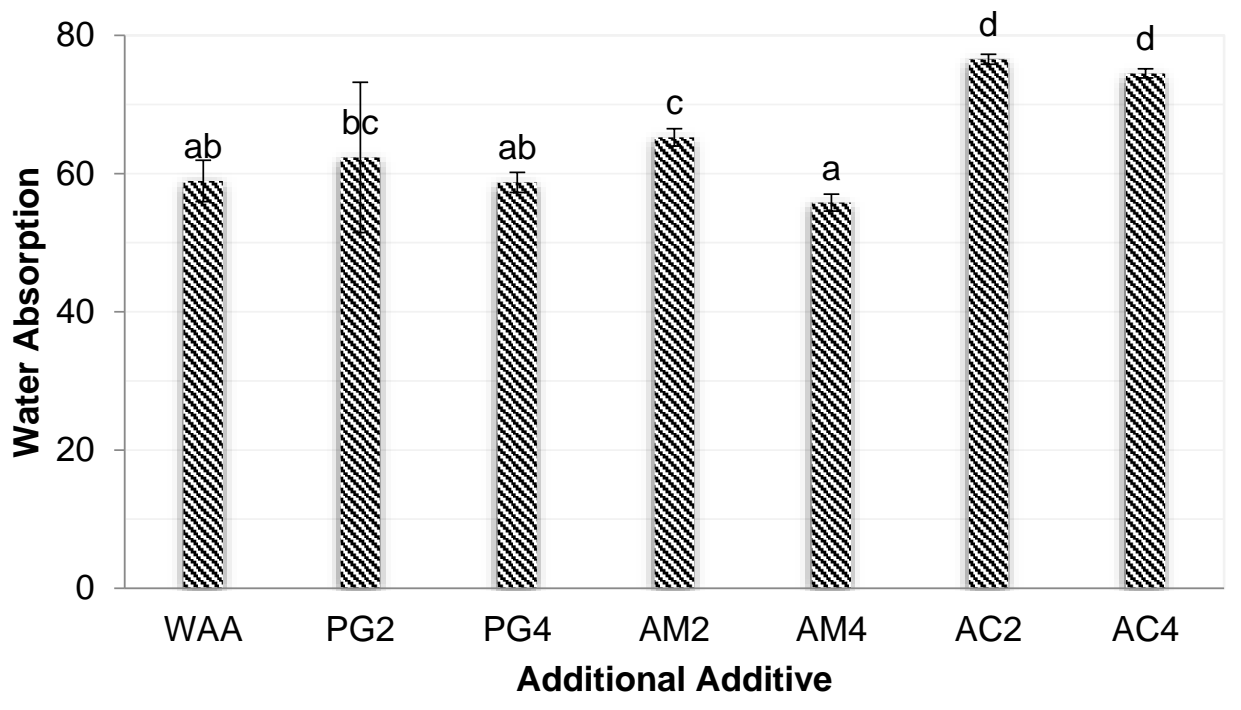

Fig. 3. Mean value of water absorption of the particleboard

Notes: Means followed by the same letters are not significantly different at $p \leq 0.05$ according to Duncan's multiple range test. The $p$-values reveal the strength of differences between factors (types of concentration $x$ concentration of additive) on the water absorption properties of the OPEFB particleboard. UF resin was present in every condition, including the WAA.

Natural fibres such as OPEFB have high hydroxyl content, which is consistent with the nature of cellulose. This which makes products formed from OPEFB susceptible to water absorption. Water absorption leads to swelling of the fibre and influences the mechanical properties of the particleboard (Meenalochani and Vijayasimha 2017). As shown in Fig. 3, the absorption of water decreased with the addition of water-soluble additive. The water-soluble polymer could effectively permeate into the wood cell walls and connected with the hydroxyl groups of the lignin and polysaccharides via covalent bonds (Qiu et al. 2018). AM4 achieved the highest water resistance (55.8\%) compared to the other particleboards produced in this study. The relatively lower thickness swelling values showed that the board was dimensionally stable, while the low water absorption capacity was an indication that the board could be employed in outdoor situations (Júnior et al. 2017). The functional group (amide) of acrylamide provides a cross-linking to the cell wall component (Marimuthu et al. 2010). New bonds from crosslinking will reduce the water sorption and swelling of the composites. Furthermore, crosslinking also improved the properties of the water barrier (López De Dicastillo et al. 2016). Apart from that, the results showed that the density of the board had a negative correlation with the water absorption. This may cause water vapour to be more accessible to the board due to reduced density (Iswanto et al. 2013). Hence, higher density resulting from the additional additive of $4 \%$ contribute to the reduction of water absorption in the particleboard. 


\section{Effect of the Additional Additive to the Mechanical Properties of Particleboard}

Figures 4 and 5 show the mechanical properties (IB and MOR) of the particleboard manufactured with different additives and concentrations. JIS A 5908:2003 required minimum IB and MOR values of $0.2 \mathrm{~N} / \mathrm{mm}^{2}$ and $13.00 \mathrm{~N} / \mathrm{mm}^{2}$, respectively. The evaluation of the mechanical properties of the OPEFB particleboard (IB and MOR) are depicted in Figs. 4 and 5.

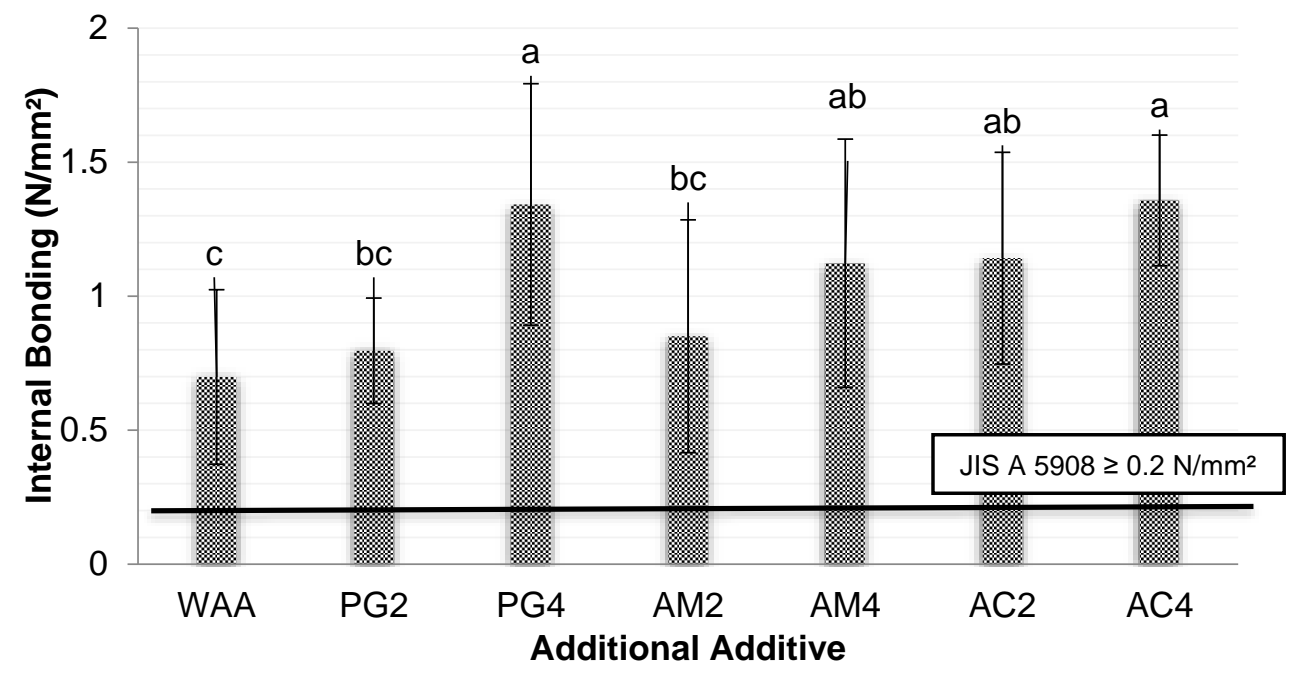

Fig. 4. Mean value of internal bonding of the particleboard

Notes: Means followed by the same letters are not significantly different at $p \leq 0.05$ according to Duncan's multiple range test. The $p$-values reveal the strength of differences between factors (types of concentration $x$ concentration of additive) on the internal bonding of the OPEFB particleboard. UF resin was present in every condition, including the WAA.

As stated by Stoeckel et al. (2013), UF resin is significantly problematic due to its inherent brittleness. Because of this characteristic, cured UF resins are very prone to cracking, and therefore exhibit poor impact resistance when applied to the wood panels. As shown in Fig. 4, the additional additive on particleboard OPEFB resulted higher IB values compared to the particleboard without additional water-soluble additives. AC4 and PG4 achieved the highest IB value with 1.36 and $1.34 \mathrm{~N} / \mathrm{mm}^{2}$ on maximum load. It is well known that IB strength is closely related to thickness swelling values as it is closely related to the inter-fibre bonding. A good bonding would result in the board with low thickness swelling and vice versa (Izani et al. 2012). While the low IB values indicates that the particles were not bonded strongly together, therefore, high volume of water were easily penetrated into spaces between particles of the porous structure (Zaidon et al. 2007). Both AC4 and PG4 obtained the highest IB strength and lowest thickness swelling value in this study (refer to Figs. 2 and 4). Acrylic resins are the preferred bonding materials as it contains functionalities (especially hydroxyl groups, e.g. from hydroxyl ethyl acrylate) that induce the chemical reactions and leads to cross-linking (Bulian and Graystone 2009; (Patcas and Eliades 2017). As stated by Hashim et al. (2011) and Mo et al. (2003), a good core bonding may be enhanced by the hydrogen bonding. The high IB strength of PG4 could be achieved with the presence of polyurethane in PEG. PEG is normally used to stabilise green wood to prevent it from cracking, splitting and shrinking (Rao et al. 2019). Due to the high polarity and the hydrogen bonding between polyurethane and the 
substrates, polyurethane was also used to bind various substrates such as metal, plastic, rubber, and wood. In acrylamide, the amide functionality provides cross linking sites that increases the inter-fibre bonding capacity (Marimuthu et al. 2010; Heydari et al. 2013).

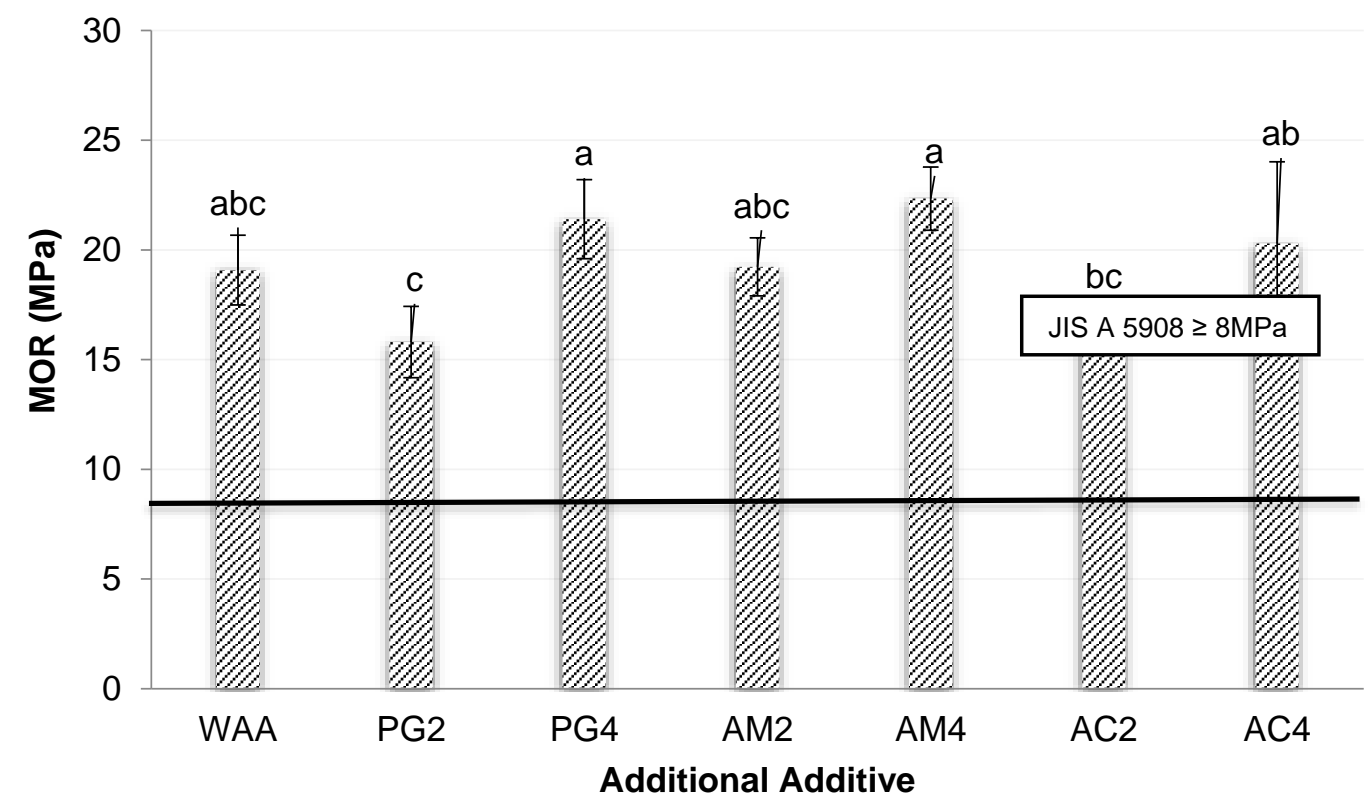

Fig. 5. Mean value of MOR of the particleboard

Notes: Means followed by the same letters are not significantly different at $p \leq 0.05$ according to Duncan's multiple range test. The $p$-values reveal the strength of differences between factors (types of concentration $x$ concentration of additive) on the MOR value of the OPEFB particleboard. UF resin was present in every condition, including the WAA.

In Figs. 4 and 5, the results show that the high concentration of the additives greatly improved the mechanical properties (IB and MOR value) of the OPEFB particleboard. According to the Li et al. (2011); Qiu et al. (2018); Trey et al. (2012), the reduction of the hydrophilic -OH groups of the cell wall components or the filling of the pore in the wood improved the mechanical properties and dimensional stability of the wood. The highest MOR values were achieved by AM4 and PG4 (Fig. 5). Conventionally, dry strength additives acrylamide worked by complementing the number of inter-fibre hydrogen bonds. As stated by Tee et al. (2019), hydrogen bonding may alter and improve the mechanical properties of wood composite panel. Hydrogen bonding causes cellulose fibres to exhibit wide ranges of strength, stiffness, and toughness in mechanical tests (Renuart and Viney 2000). Particleboards treated with PEG have higher MOR value than the particleboards without additional additive. The properties of the particleboard were completely altered by the plasticization effect of PEG, which led to the high MOR value. PEG contributes in high elongation at break, and better impact resistance to the particleboard (Biron 2018). Besides, the MOR value for AC4 was higher in comparison of particleboard without additional additive. This was due to acrylic resin has high hardness and superior chemical resistance (Xu et al. 2009). 


\section{CONCLUSIONS}

1. The use of water-soluble additives can open new opportunities for particleboard manufacturing using palm oil industry waste. All particleboards with additional watersoluble additives achieved better performance on the physical and mechanical properties in comparison with particleboard without a water-soluble additive.

2. Statistical analyses indicates that the concentration of additional water-soluble additive influenced the physical properties of particleboard. The decrease in thickness swelling and water absorption was found to be statistically significant when compared with the particleboard without water-soluble additives.

3. Regardless of the types of water-soluble additive, $4 \%$ concentration of additive achieved higher mechanical properties including internal bonding and modulus of rupture (MOR) of oil palm empty fruit bunch (OPEFB) particleboard compared to $2 \%$ concentration of additive. Particleboards with additional $4 \%$ of acrylamide or polyethylene glycol (PEG) achieved the highest modulus of rupture (mean value 22 $\mathrm{MPa}$ ), internal bonding strength (mean value $1 \mathrm{~N} / \mathrm{mm}^{3}$ ), and the lowest thickness swelling (mean value 9\%).

4. An addition of additive up to of $4 \%$ concentration did not further deteriorate the physical and mechanical properties of OPEFB particleboard. All the particleboards produced with $4 \%$ of water-soluble additive achieve the requirements of JIS A 5908:2003 for the physical and mechanical properties.

\section{ACKNOWLEDGMENTS}

The study was supported by the Fundamental Research Grant Scheme (FRGS) (Ref. No: FRGS/1/2019/WAB07/UPM/02/2 awarded by the Malaysia Ministry of Higher Education (MOHE). The authors also thank all project members for support and collaboration.

\section{REFERENCES CITED}

Amazio, P., Avella, M., Errico, M. E., Gentile, G., Balducci, F., Gnaccarini, A., Moratalla, J., and Belanche, M. (2011). "Low formaldehyde emission particleboard panels realized through a new acrylic binder," Journal of Applied Polymer Science 122, 2779-2788. DOI: 10.1002/app

Ammar, S., Ma, I. A. W., Ramesh, K., and Ramesh, S. (2019). "Polymers-based nanocomposite coatings," in: Nanomaterials-Based Coatings, Elsevier, pp. 9-39.

Behzad, T., and Sain, M. (2004). "Cure study of an acrylic resin to develop natural fiber composites," Journal of Applied Polymer Science 92(2), 757-762. DOI: 10.1002/app.20046

Biron, M. (2018). Thermoplastics and Thermoplastis Composites, William Andrew Applied Science.

Brahmia, F. Z., Horváth, P., and Alpar, T. (2020). "Effect of pre-treatments and additives on the improvement of cement wood composite: A review," BioResources 15(3), 
7288-7308. DOI: 10.15376/biores.15.3.Brahmia

Bulian, F., and Graystone, J. A. (2009). "Raw materials for wood coatings (1)-film formers (binders, resins and polymers)," in: Wood Coatings, Elsevier Science, 53-94.

Chen, J., Spear, S. K., Huddleston, J. G., and Rogers, R. D. (2005). "Polyethylene glycol and solutions of polyethylene glycol as green reaction media," Green Chemistry 7(2), 64-82. DOI: 10.1039/b413546f

Chen, W., Parette, R., Zou, J., Ã, F. S. C., and Dempsey, B. A. (2007). “Arsenic removal by iron-modified activated carbon," Water Research, 41, 1851-1858. DOI: 10.1016/j.watres.2007.01.052

Chin, K. L., H'ng, P. S., Chai, E. W., Khoo, P. S., Lee, C. L., and Go, W. Z. (2019). "Valorization of lignocellulosic food industry waste in Malaysia by accelerated cocomposting method: changes in physicochemical and microbial community," Waste and Biomass Valorization, Springer Netherlands, 11(9), 4871-4884. DOI: 10.1007/s12649-019-00825-4

Das, S., Matuana, L. M., and Heiden, P. (2008). “Thermoplastic polymers as modifiers for urea-formaldehyde wood adhesives. III. In situ thermoplastic-modified wood composites," Journal of Applied Polymer Science 107(5), 3200-3211. DOI: 10.1002/app

Fredi, G., Dorigato, A., Fambri, L., Lopez-Cuesta, J.-M., and Pegoretti, A. (2019). "Synergistic effects of metal hydroxides and fumed nanosilica as fire retardants for polyethylene," Flame Retardancy and Thermal Stability of Materials 2(1), 30-48. DOI: $10.1515 /$ flret-2019-0004

Gopala, A., Wu, H., Harris, F., and Heiden, P. (1998). "Investigation of readily processable thermoplastic-toughened thermosets. I. BMIs toughened via a reactive solvent approach," Journal of Applied Polymer Science 69(3), 469-477. DOI: 10.1002/(sici)1097-4628(19980718)69:3<469::aid-app6>3.3.co;2-1

Harun, J. (2018). "Maskayu," Malaysian Timber Industry Board, Kuala Lumpur, 1, 1-32. Hashim, R., Nadhari, W. N. A. W., Sulaiman, O., Kawamura, F., Hiziroglu, S., Sato, M., Sugimoto, T., Seng, T. G., and Tanaka, R. (2011). "Characterization of raw materials and manufactured binderless particleboard from oil palm biomass," Materials and Design 32(1), 246-254. DOI: 10.1016/j.matdes.2010.05.059

Heebink, B. G., and Hefty, F. V. (1968). "Steam post-treatments to reduce thickness swelling of particleboard," Note FPL-RN-0187. Madison, WI: US Department of Agriculture, Forest Service, Forest Products Laboratory.

Heydari, S., Ghasemian, A., and Afra, E. (2013). "Effects of refining and cationic polyacrylamide on strength properties of paper made from old corrugated container (OCC)," World of Sciences Journal, (Apri 1).

Huang, Y., L., H. D., Kinloch, A. J., Riew, C. K., and Kinloch, A. J. (1993). "Mechanisms of toughening thermoset resins," Advances in Chemistry, 233, 1-34.

Ismail, M., Jegatheswaran, R., Shukri, M., Mohamad Roslan, M. K., and Izran, K. (2012). "Market assessment on the potential of oil palm empty fruit bunch (OPEFB) particleboard in Malaysia's wood-based industries," Pertanika Journal of Tropical Agricultural Science 35(3), 581-592.

Iswanto, A. H., Febrianto, F., Hadi, Y. S., Ruhendi, S., and Hermawan, D. (2013). "The effect of pressing temperature and time on the quality of particle board made from jatropha fruit hulls treated in acidic condition," MAKARA Journal of Technology Series 17(3), 145-151. DOI: 10.7454/mst.v17i3.2930 
Izani, M. N., Paridah, M. T., Astimar, A. A., Nor, M. M., and Anwar, U. M. K. (2012). "Mechanical and dimensional stability properties of medium-density fibreboard produced from treated oil palm empty fruit bunch," Journal of Applied Sciences 12, 561-567.

Júnior, H. S., Fiorelli, J., and Dos Santos, S. F. (Eds.). (2017). Sustainable and Nonconventional Construction Materials Using Inorganic Bonded Fiber Composites, Woodhead Publishing, Duxford.

Killmann, W., and Hong, L. T. (2000). "Rubberwood - The success of an agricultural byproduct," UNASYLVA-FAO-, 66-72.

Kusnin, N., Syed, M. A., and Ahmad, S. (2015). "Toxicity, pollution and biodegradation of acrylamide - A mini review," Journal of Biochemistry, Microbiology and Biotechnology 3(2), 6-12.

La Mantia, F. P., and Morreale, M. (2011). "Green composites: A brief review," Composites Part A: Applied Science and Manufacturing, Elsevier Ltd, 42(6), 579588. DOI: 10.1016/j.compositesa.2011.01.017

Li, Y., Dong, X., Liu, Y., Li, J., and Wang, F. (2011). "Improvement of decay resistance of wood via combination treatment on wood cell wall: Swell-bonding with maleic anhydride and graft copolymerization with glycidyl methacrylate and methyl methacrylate," International Biodeterioration and Biodegradation, Elsevier Ltd, 65(7), 1087-1094. DOI: 10.1016/j.ibiod.2011.08.009

López De Dicastillo, C., Rodríguez, F., Guarda, A., and Galotto, M. J. (2016). "Antioxidant films based on cross-linked methyl cellulose and native Chilean berry for food packaging applications," Carbohydrate Polymers, Elsevier Ltd., 136, 10521060. DOI: 10.1016/j.carbpol.2015.10.013

Luo, J., Zhang, J., Gao, Q., Mao, A., and Li, J. (2019). “Toughening and enhancing melamine-urea-formaldehyde resin properties via in situ polymerization of dialdehyde starch and microphase separation," Polymers 11(7). DOI: 10.3390/polym11071167

Marimuthu, P., Vetrivelayutham, S., and Sundarakumar, D. (2010). “Anionic acrylamide co-polymer as dry strength additive for paper," Tappi J. 22(No.3.9), 131-136.

Meenalochani, K., and Vijayasimha, R. (2017). "A review on water absorption behavior and its effect on mechanical properties of natural fibre reinforced composites," in: International Journal of Innovative Research in Advanced Engineering (IJIRAE), 143-147.

Mekonnen, T., Mussone, P., Khalil, H., and Bressler, D. (2013). "Progress in bio-based plastics and plasticizing modifications," Journal of Materials Chemistry A 1(43), 13379-13398. DOI: $10.1039 / \mathrm{c} 3$ ta12555f

Mo, X., Cheng, E., Wang, D., and Sun, X. S. (2003). "Physical properties of mediumdensity wheat straw particleboard using different adhesives," Industrial Crops and Products 18(1), 47-53. DOI: 10.1016/S0926-6690(03)00032-3

Owodunni, A. A., Lamaming, J., Hashim, R., Abdulwahab Taiwo, O. F., Hussin, M. H., Mohamad Kassim, M. H., Bustami, Y., Sulaiman, O., Mohamad Amini, M. H., and Hiziroglu, S. (2020). "Properties of green particleboard manufactured from coconut fiber using a potato starch based adhesive," BioResources 15(2), 2279-2292. DOI: 10.15376/biores.15.2.2279-2292

Patcas, R., and Eliades, T. (2017). "Enamel alterations due to orthodontic treatment," in: Orthodontic Applications of Biomaterials, Woodhead Publishing. 
Peter, P., Nik Soh, N. M. Z., Akasah, Z. A., and Mannan, M. A. (2020). 'Durability evaluation of cement board produced from untreated and pre-treated empty fruit bunch fibre through accelerating ageing," in: IOP Conference Series: Materials Science and Engineering, 012019. DOI: 10.1088/1757-899X/713/1/012019

Popescu, C. M., and Pfriem, A. (2020). "Treatments and modification to improve the reaction to fire of wood and wood based products-An overview," Fire and Materials 44(1), 100-111. DOI: 10.1002/fam.2779

Qiu, H., Yang, S., Han, Y., Shen, X., Fan, D., Li, G., and Chu, F. (2018). "Improvement of the performance of plantation wood by grafting water-soluble vinyl monomers onto cell walls," ACS Sustainable Chemistry and Engineering 6(11), 14450-14459. DOI: 10.1021/acssuschemeng.8b03112

Radzi, A. M., Sapuan, S. M., Jawaid, M., and Mansor, M. R. (2019). "Water absorption, thickness swelling and thermal properties of roselle/sugar palm fibre reinforced thermoplastic polyurethane hybrid composites," Journal of Materials Research and Technology 8(5), 3988-3994. DOI: 10.1016/j.jmrt.2019.07.007

Rahayu, D. E., Wirjodirdjo, B., and Hadi, W. (2019). "Availability of empty fruit bunch as biomass feedstock for sustainability of bioenergy product (system dynamic approach)," in: The $2^{\text {nd }}$ International Conference on Science, Mathematics, Environment, and Education AIP Conference Proceedings, Central Java, Indonesia, 0200095. DOI: 10.1063/1.5139827

Rao, J., Jiang, J., Prosper, N. K., Yang, X., Liu, T., Cai, W., Wang, H., and Sun, F. (2019). "Combination of polyethylene glycol impregnation and paraffin heat treatment to protect round bamboo from cracking," Royal Society Open Science 6(11), 4-14. DOI: 10.1098/rsos.190105

Renuart, E., and Viney, C. (2000). Biological Fibrous Materials: Self-assembled Structures and Optimised Properties, M. Elices (ed.), Pergamon/Elsevier Science, Oxford, DOI: 10.1016/S1470-1804(00)80012-7

Stoeckel, F., Konnerth, J., and Gindl-Altmutter, W. (2013). "Mechanical properties of adhesives for bonding wood - A review," International Journal of Adhesion and Adhesives 45, 32-41. DOI: 10.1016/j.ijadhadh.2013.03.013

Sumardi, I., and Suzuki, S. (2014). "Dimensional stability and mechanical properties of strandboard made from bamboo," BioResources 9(1), 1159-1167. DOI: 10.15376/biores.9.1.1159-1167

Surendran, S., and Ng, J. (2020). "Cover story: Diverging paths in Malaysia's rubber industry," The Edge Malaysia.

Syeed SaifulAzry, O. A. E., Paridah, M. T., Chuah, T. G., Lee, S. H., Juliana, A. H., and Lee, C. H. (2019). "Particleboard manufactured from rubberwood rrim 2002 clone planted with different fertilizer treatment," International Journal of Recent Technology and Engineering 8(2 Special Issue 4), 398-402. DOI: 10.35940/ijrte.B1077.0782S419

Tee, H. T., Koynov, K., Reichel, T., and Wurm, F. R. (2019). "Noncovalent hydrogen bonds tune the mechanical properties of phosphoester polyethylene mimics," ACS Omega 4(5), 9324-9332. DOI: 10.1021/acsomega.9b01040

Tepe, Y., and Çebi, A. (2019). "Acrylamide in environmental water: A review on sources, exposure, and public health risks," Exposure and Health 11(1), 3-12. DOI: 10.1007/s12403-017-0261-y

Trey, S., Jafarzadeh, S., and Johansson, M. (2012). "In situ polymerization of polyaniline 
in wood veneers," NWBC 2012 - 4th Nordic Wood Biorefinery Conference, 427-428.

Vafaeezadeh, M., and Hashemi, M. M. (2015). "Polyethylene glycol (PEG) as a green solvent for carbon-carbon bond formation reactions," Journal of Molecular Liquids 207(March 2015), 73-79. DOI: 10.1016/j.molliq.2015.03.003

Vivek, R. (2017). "Eco-friendly and biocompatible acrylic resins - A review," J. Dent. Oral Health 3(1), 1-3.

Wei, Y. M., and Tomita, B. (2001). "Effects of five additive materials on mechanical and dimensional properties of wood cement-bonded boards," Journal of Wood Science 47(6), 437-444. DOI: 10.1007/BF00767895

Xiong, X., Ma, Q., Yuan, Y. Y., Wu, Z., and Zhang, M. (2020). “Current situation and key manufacturing considerations of green furniture in China: A review," Journal of Cleaner Production 267, article no. 121957. DOI: 10.1016/j.jclepro.2020.121957

Xu, K., Zhou, S. X., and Wu, L. M. (2009). "Preparation and properties of thermosetting acrylic coatings using titanium-oxo-cluster as a curing agent," Chinese Journal of Polymer Science 27(03), 351-358.

Yusof, A. (2019). "Malaysia to cap $6.5 \mathrm{~m}$ ha of oil palm plantations by 2023," New Straits Times.

Zaidon, A., Norhairul Nizam, A. M., Mohd Nor, M. Y., Abood, F., Paridah, M. T., Nor Yuziah, M. Y., and Jalaluddin, H. (2007). "Properties of particleboard made from pretreated particles of rubberwood, EFB and rubberwood-EFB blend," Journal of Applied Sciences 7(8), 1145-1151. DOI: 10.3923/jas.2007.1145.1151

Article submitted: November 5, 2020; Peer review completed: January 11, 2021; Revised version received: July 3, 2021; Accepted: July 4, 2021; Published: July 22, 2021.

DOI: $10.15376 /$ biores.16.3.6159-6173 